\title{
Effect of mangrove restoration on crab burrow density in Luoyangjiang Estuary, China CrossMark
}

\author{
Wei Li, Lijuan Cui', Manyin Zhang, Yifei Wang, Yaqiong Zhang, Yinru Lei and Xinsheng Zhao
}

\begin{abstract}
Background: Mangrove restoration seeks to restore or rebuild degraded mangrove systems. The methods of mangrove restoration include ecological projects and restoration-oriented technologies, the latter of which are designed to restore the structure, processes as well as related physical, chemical and biological characteristics of wetlands and to ensure the provision of ecosystem services. As important components of mangrove ecosystem, benthic organisms and crabs play a key role in nutrient cycling. In addition, mangrove restoration, such as vegetation restoration measures, can lead to changes in the benthic faunal communities. This study investigates whether the presence of different mangrove species, age and canopy cover of mangrove communities affect the density of crab burrows.

Methods: The Luoyangjiang Estuary, in the southeast of Fujian Province, was selected as our research area. A survey, covering 14 sites, was conducted to investigate the impacts of mangrove restoration on the density of crab burrows in four rehabilitated forests with different stand ages and canopy.

Results: It was found that differences in vegetation types had a large impact on crab density and that the density of crab burrows was lower on exposed beaches (non-mangrove) than under mature Kandelia candel, Aegiceras corniculatum and Avicennia marina communities. In general, the amount of leaf litter and debris on mangrove mudflats was greater than on the beaches as food sources for crabs. Two-factor analysis of variance (ANOVA) shows that changes in mangrove species and age since restoration had different effects on crab burrow density. The effect of canopy cover was highly significant on crab burrow density.

Conclusions: The results suggest that in the process of mangrove restoration the combined effects of mangrove stand age, canopy cover and other factors should be taken into account. This study further supports the findings of the future scientific research and practice on mangrove restoration and management measures.
\end{abstract}

Keywords: Canopy; Crab burrow density; Mangrove; Restoration

\section{Background}

Due to increasing human population and rapid economic development, mangrove communities are experiencing a significant decline globally. The decline of mangrove communities leads to the shortening of shorelines, which has decreased from $198 \mathrm{~km}$ in 1980 to 158 $\mathrm{km}$ in 1990, with only $147 \mathrm{~km}$ remaining in 2003 (Food and Agricultural Organization FAO 2003). During the past several decades, the extent of mangroves along the South China coast sharply decreased as a result of land reclamation in the 1970s and aquaculture in the early

* Correspondence: wetlands108@126.com

Beijing Key Laboratory of Wetland Services and Restoration, Institute of Wetland Research, Chinese Academy of Forestry, Beijing 100091, P. R. China 1980s; the area of mangroves dropped from 400,000420,000 ha in 1956 to 21,283 ha in 1986 and then to 15,122 ha in the early 1990s (Zheng et al. 2003; Fan 2000). Since the late 1970s, governments worldwide have adopted a series of measures to restrain the degradation and loss of mangroves. Mangroves have been restored, to varying extents, in the Americas (Brockmeyer et al. 1997; Lewis 2000), Oceania (Saenger 1996) and Asia (Sanyal 1998). In China, the area of mangroves reached 22,025 ha by 2001 , of which almost 7,000 ha was restored or recovered naturally (Fan 2000). However, large-scale mangrove restoration activities still face many challenges.

\section{实


Mangrove restoration has important impacts on the environment (Lin 1999; Marcelo and Cohen 2003; Giri et al. 2007; Giulia et al. 2008), which are related to factors such as propagation of population dynamics, primary productivity and the relationships between changes in mangrove landscapes and biodiversity or biogeochemical cycles (Stacy and Marvin 2002; Phan and Jacques 2007; Rubih et al. 2007; Paling et al. 2008). Mangrove restoration can lead to changes in benthic faunal communities that play a significant role in the restoration of mangrove functions (Macintosh et al. 2002; Cui and Stephane 2006; Rubih et al. 2007; Primavera and Esteban 2008; Roslan et al. 2010). For example, Li et al. (2007) focused on the effects of Aegiceras corniculatum restoration on macro-benthic animals in the Jiulongjiang River estuary. His research consisted of three forests, i.e., two replanted forests five- and ten-years old, a natural mature forest and a plot of barren beach, in order to explore the relationship between macro-benthic animal populations and the length of time since restoration. He found that species abundance and composition of macro-benthic animals in A. corniculatum forests were negatively correlated with time since restoration. Significant differences were found in populations of dominant macro-benthic animal species between mangrove forests and barren beaches and different species compositions were found in mangrove forests of varying ages.

Other studies have shown that biotic factors had an important effect on the structure of mangrove forests and ecological processes (Carlos et al. 2005; Alberti et al. 2008; Erik 2008; Samidurai et al. 2012; Wang et al. 2014; Bui and Lee 2015). In Australia, the research of Robertson and Daniel (1989) demonstrated that crabs from mangroves had a significant impact on energy flows; crabs are particularly important seed predators. In Belize, Feller and Chamberlain (2007) found landscape heterogeneity of the biotic and abiotic environment with species-specific effects on community structures and trophic interactions. Subsequent experimental work revealed burrowing by crabs had significant effects on sediment chemistry, forest growth and productivity (Smith et al. 1991). The various crab species respond differently to vegetation. In Kenya, Sesarma guttatum (family Grapsidae) preferred shaded habitats and are most common in regions with an established mangrove canopy (Ruwa 1997). Steinke et al. (1993) showed the age of litter was more important than its source in determining habitat preferences of crabs.

Exploring the relationship between mangrove restoration and macro-benthic fauna is essential for mangrove ecosystem restoration (Macintosh et al. 2002; Morrisey et al. 2003; Gawlik 2006). The objective of our study was to explore the impact of restoration on the density of crab burrows in several rehabilitated mangrove forests of various ages (in the timing of restoration) and different canopy covers in the Luoyangjiang Estuary, China.

\section{Methods}

\section{Study area}

The Luoyangjiang Estuary is located in the southeast of Fujian Province $\left(24^{\circ} 51^{\prime} \mathrm{N}-24^{\circ} 58^{\prime} \mathrm{N}\right.$ and $118^{\circ} 37^{\prime} \mathrm{E}-118^{\circ}$ $\left.43^{\prime} \mathrm{E}\right)$. This region has a subtropical maritime monsoon climate. The average annual temperature is between $19.5-21.0{ }^{\circ} \mathrm{C}$, with a minimum temperature of $0{ }^{\circ} \mathrm{C}$ and a maximum of $38{ }^{\circ} \mathrm{C}$. The average annual amount of sunshine is between 1,892 and 2,131 $\mathrm{h}$ and the mean annual number of growth degree days (GDDs) lies between $5,610{ }^{\circ} \mathrm{C}$ and $7,250{ }^{\circ} \mathrm{C}\left(\geq 10{ }^{\circ} \mathrm{C}\right)$. The mean annual precipitation ranges from 1,009 to $1,200 \mathrm{~mm}$ and the mean annual evaporation from 1,467 to 2,022 mm (Huang 2004). Three mangrove species, i.e., Kandelia candel (L.) Duce., Aegiceras corniculatum Blanco. and Avicennia marina (Forsk) Vierh. have been found in the estuary, along with two herbaceous species of Spartina (S. angelica and S. alterniflora).

Luoyangjiang Estuary, a typical tectonic bay, has semi-diurnal tides ranging from $1.2-6.7 \mathrm{~m}$ in height. The salinity of the surface soil $(2-5 \mathrm{~cm})$ is between 10.8 and $17.0 \mathrm{mS} \cdot \mathrm{cm}^{-1}$ (Liu 2010). Large mangroves areas were harvested for firewood and the construction of sea walls in the 1990s. Other human activities, such as fishing, also increased the problem of pollution. By 2001, mangrove forests had been torn apart into variously shaped patches. The invasion of S. angelica and $S$. alterniflora also impacted mangroves to some extent. The work of mangroves restoration in the estuary started with an increase in area in 2003 (Li et al. 2009). For example, Huian County established the 877 ha Luoyangjiang Nature Reserve on 26 February 2002. To protect mangroves, Fujian Province established the 7,039 ha Quanzhou Bay Estuarine Wetland Provincial Nature Reserve on 24 September 2003, which includes previously protected areas (Liu 2010).

\section{Vegetation and crab burrow sampling}

We conducted a survey in May 2008 that covered 14 sites (Table 1). This research selected three $K$. candel forests, i.e., a 1-year old, a 4-year old and a natural mature forest; three $A$. corniculatum forests again consisting of a 1-year old, a 4-year old and a natural mature forest; a natural mature $A$. marina forest and a beach habitat without mangroves. This beach habitat site used to be a mangrove habitat; however, the site was demolished due to firewood harvesting and sea wall construction. We also sampled mature $A$. corniculatum and $K$. candel forests, both with low, middle and high canopy covers. At each site, three $10 \mathrm{~m} \times 10 \mathrm{~m}$ plots were established for sampling. Tree height $(\mathrm{cm})$, stem basal 
diameter $(\mathrm{cm})$ and canopy cover (\%) were measured in each plot. Tree height was measured with a tape and stem basal diameter with a vernier caliper (CN61M/ 150, Zhongxi, Inc., Beijing, China). The canopy vegetation cover was estimated at noon of a sunny day to decrease the relative amount of light intensity in the mangrove, compared with that on the outside. Canopies were classified as low canopy cover, when $10-39 \%$ of the sky was obstructed by tree canopies, middle canopy cover with 40-69\% obstruction of the sky and high canopy cover, where $70-100 \%$ of the sky was obstructed by tree canopies. (http://ecoplexity.org/files/Measuring_Canopy_Cover_lesson_plan.pdf).

The number of burrows has been widely used for estimating the population of mangrove crab species (e.g., Warren 1990; Skov et al. 2002; Salgado and McGuinness 2006). At each site, three $10 \mathrm{~m} \times 10 \mathrm{~m}$ plots (the same plots that were used to sample the vegetation) were established for sampling with at least $10 \mathrm{~m}$ distance between plots. Each site contained eight $1 \mathrm{~m} \times 1 \mathrm{~m}$ subplots. Crab burrows were sampled during ebb tides, when we pushed a steel frame into the sediment surface. In order to minimize the effect of various environmental factors (e. g. weather, sea conditions) on burrow density, we used a temporal replication method to select sampling plots. For example, sampling plots in our investigation were chosen at similar elevations to avoid the effect of tidal levels on the distribution of macro-benthic fauna. Real-time GPS was used to measure elevations (GPSMAP 62sc, Garmin International, Inc., Olathe, KS, USA). Burrow counts were finished after 15 days and the complete survey of all plots was finished within 4-5 $h$ on each survey day. To avoid possible time bias, the sequence of field measurements was chosen randomly (Serena et al. 2009).

\section{Data analysis}

Two-factor analysis of variance (ANOVA) was used to test whether crab burrow density was significantly affected by mangrove species and age since restoration. SPSS software was used to analyze the mangrove species and canopy cover. Mean values are reported with $95 \%$ confidence intervals (Sokal and Rohlf 1995; Skov et al. 2002).

A non-parametric multidimensional scaling analysis (NMDS) was carried out to examine differences in crab burrow density between the various mangrove forests and on the beach of the Luoyangjiang Estuary, China. NMDS analyses were performed according to Granek and Frasier (2007) and Błażewicz-Paszkowycz et al. (2014). Correlation analysis was used to examine the relationship of different canopies and crab burrow density under $A$. corniculatum and $K$. candel covers PC-ORD v.4 (MjM Software, Gleneden Beach, OR) and Origin8.0 (OriginLab Corporation) were used for the statistical analyses.

\section{Results and discussion}

\section{Effects of plant species and restoration time}

Significant differences were found in the mean density of crab burrows between the beach and mature sites of $K$. candel, A. corniculatum and A. marina $(p<0.05)$ sites.

Table 1 Information on mangrove communities studied

\begin{tabular}{|c|c|c|c|}
\hline Type & Average tree height $(\mathrm{cm})$ & Average stem basal diameter $(\mathrm{cm})$ & Note \\
\hline 1-year old K. candel forest & 70 & 1.05 & $\begin{array}{l}\text { Spaces between rows } 80 \mathrm{~cm} \text { (K. candel was } \\
\text { planted in 2007, 1-year old in 2008) }\end{array}$ \\
\hline 4-year old K. candel forest & 85 & 1.88 & $\begin{array}{l}\text { Spaces between rows } 80 \mathrm{~cm} \text { (K. candel was } \\
\text { planted in 2004, 4-year old in 2008) }\end{array}$ \\
\hline Natural mature $K$. candel forest & 123 & 3.83 & - \\
\hline 1-year old A. corniculatum forest & 147 & 5.17 & $\begin{array}{l}\text { Spaces between rows } 100 \mathrm{~cm} \text { (A. corniculatum } \\
\text { was planted in 2007, 1-year old in 2008) }\end{array}$ \\
\hline 4-year old A. corniculatum forest & 182 & 7.38 & $\begin{array}{l}\text { Spaces between rows } 100 \mathrm{~cm} \text { (A. corniculatum } \\
\text { was planted in 2004, 4-year old in 2008) }\end{array}$ \\
\hline Natural mature A. corniculatum forest & 201 & 10.62 & - \\
\hline Natural mature A. marina forest & 93 & 3.08 & - \\
\hline Beach & - & - & - \\
\hline \multirow[t]{2}{*}{ A. corniculatum mature forest } & 195 & 9.81 & Low canopy cover \\
\hline & 199 & 10.48 & Middle canopy cover \\
\hline \multirow[t]{4}{*}{ K. candel mature forest } & 206 & 11.18 & High canopy cover \\
\hline & 108 & 3.61 & Low canopy cover \\
\hline & 126 & 3.85 & Middle canopy cover \\
\hline & 136 & 4.04 & High canopy cover \\
\hline
\end{tabular}




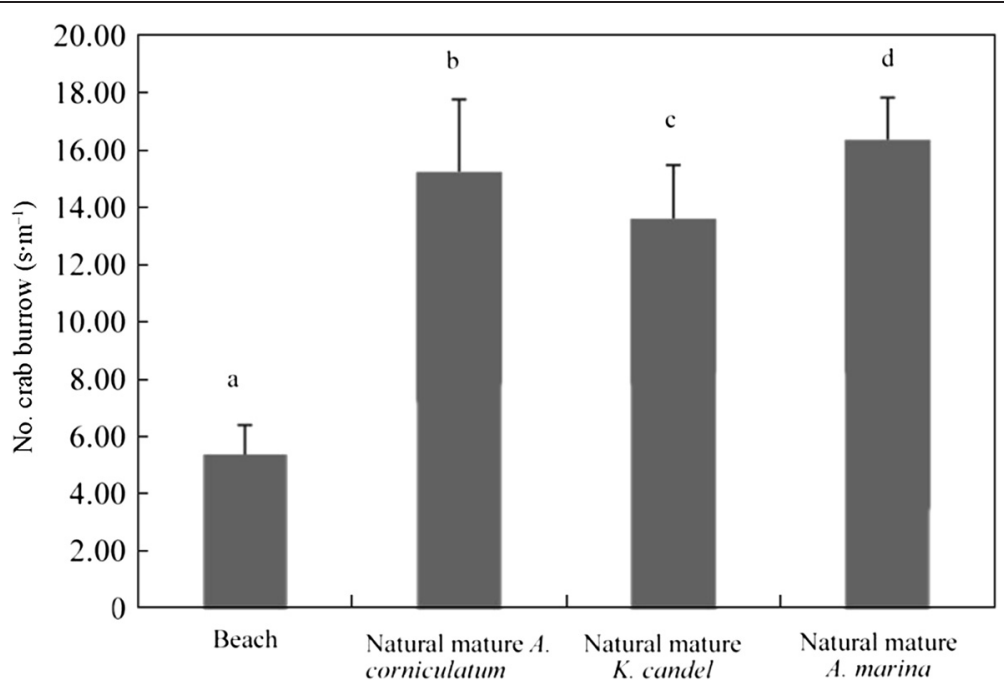

Fig. 1 Crab burrow density under different plant species and beach. Columns with the same letter do not show significant differences; different letters indicate significant differences $(p<0.05)$. The same comments apply to other figures

The sequence of crab burrow density was A. marina $>A$. corniculatum $>K$. candel $>$ beach. Densities ranged from a mean of $16.4 \mathrm{~m}^{-2}$ for the $A$. marina site to $5.4 \mathrm{~m}^{-2}$ at the beach sites (Fig. 1). The present study showed that the communities of three mangrove species supported higher densities of crab burrows than the unshaded beach. Crabs belonging to the family Ocypodidae are the most common species in the Luoyangjiang Estuary, which consume a large amount of the mangrove plant litter. Their rate of consumption (this rate is defined as a percentage of leaf litter production) can reach $100 \%$ (Poovachiranon and Tantichodok 1991). Physical and chemical soil sediment properties, such as salinity, the total amount of nitrogen and sulfide, can vary in the many mangrove communities and these in turn affect the distribution of benthic organisms. In general, leaf litter and debris on mangrove mudflats are greater than those on the beach, providing a larger number of food sources for crabs (e. g. Micheli et al. 1991; Slim et al. 1997; Schories et al. 2003). In our study, significant differences were found among mature $A$. corniculatum and 1- and 4-year old $A$. corniculatum sites $(p<0.05)$ (Fig. 2$)$. The 1 -year old $A$. corniculatum mangroves had fewer open flats, resulting in less algal biomass and smaller numbers of crabs. In $A$. corniculatum forests, crabs (i.e. sesarmid crabs and Uca fiddler crabs) were more intensively affected by vegetation, which

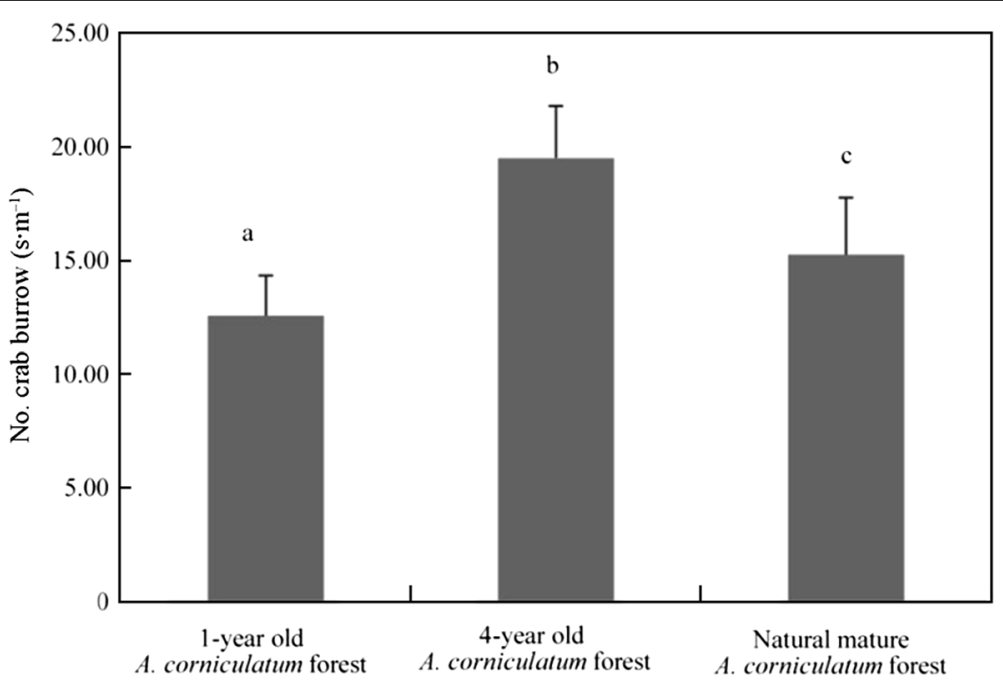

Fig. 2 Crab burrow density under A. corniculatum of different lengths of time since restoration 


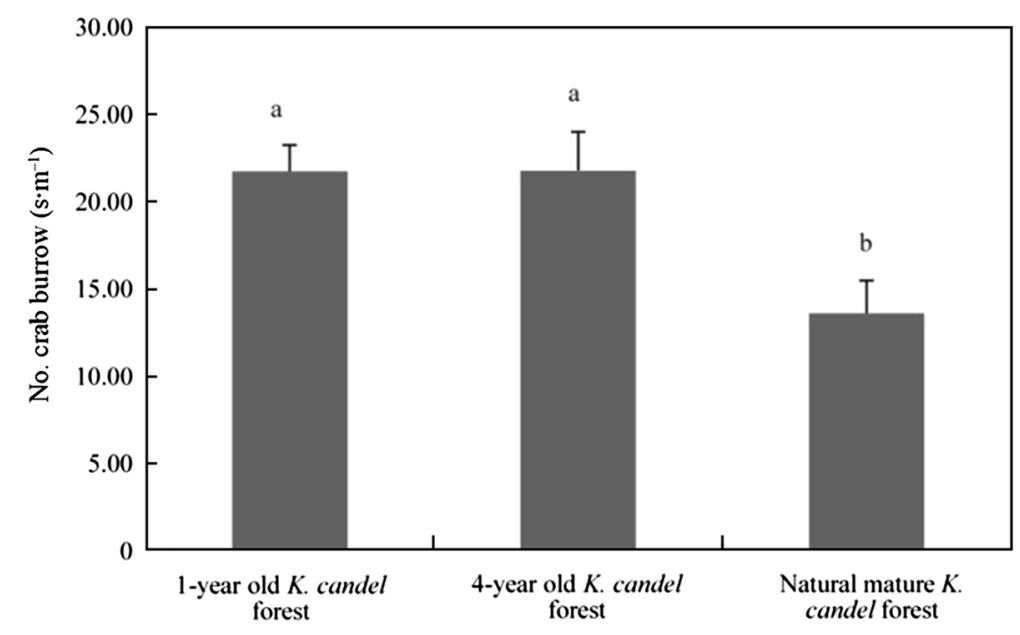

Fig. 3 Crab burrow density under $K$. candel of different lengths of time since restoration

supplies nutrients to herbivorous crabs with leaf litter (Chen et al. 2007). However, mangroves are not suitable for Uca crabs for they communicate by visual signaling or waving. Thus, their communication is affected by the complex structure of mangroves (Teal 1958; Chen et al. 2007; Chen and Ye 2011). Significant differences were found among mature $K$. candel and 1- and 4-year old $K$. candel sites $(p<0.05)$, where the mature $K$. candel had significantly lower crab density than the 1- and 4- year old sites. The pattern of crab burrow density did not show clear differences between 1- and 4-year old K. candel sites (Fig. 3). The abundance of burrows varied with stand age which, to some extent, is related with the maturity of $K$. candel. Chen et al. (2007) explained that macro-benthic faunal communities and $K$. candel mangrove vegetation may mature about 20 years after being planted. Two-factor ANOVA showed that plant species and stand age significantly affected the density of crab burrows $(p<0.001)$ (Table 2).

The average crab burrow density under $K$. candel trees was higher than that under $A$. corniculatum trees. The changes of plant species, population and composition may affect this density (Chen et al. 2007). Densities of crab burrows under 1-year old $\left(22 \pm 1.5 \mathrm{~m}^{-2}\right)$ and 4-year old $K$. candel trees $\left(22 \pm 2.2 \mathrm{~m}^{-2}\right)$ were similar. This

Table 2 Multiple comparisons of the effect of different mangrove canopy densities and time since restoration and the density of crab burrows

\begin{tabular}{llcrl}
\hline Type & Source & Mean square & \multicolumn{1}{l}{$F$} & \multicolumn{1}{l}{$p$} \\
\hline A & Plant species (P) & 436.765 & 46.952 & $0.000^{* * *}$ \\
& Stand age (S) & 527.895 & 56.748 & $0.000^{* * *}$ \\
B & Plant species (P) & 81.636 & 7.326 & $0.008^{* *}$ \\
& Canopy cover (C) & 805.130 & 72.254 & $0.000^{* * *}$ \\
\hline
\end{tabular}

Note: **: $p<0.01, * * *: p<0.001$ result suggests that crabs are not affected by tree age during the early stages of $K$. candel restoration. However, the $K$. candel community and crab burrow density stabilized after a period of time (Chen et al. 2007). Crab burrow density under $K$. candel trees was generally higher than that under $A$. corniculatum trees of the same age (1- and 4-year old), because some characteristics of $K$. candel could delay the impact of tides on crab burrows since its buttresses and aerial roots solidify the soil and protect the crab burrows, especially those of the smaller crabs (Cyril et al. 2009; Gianluca 2009). Since $A$. corniculatum does not provide adequate hiding places for crabs this species, in contrast, has lower crab burrow densities around its base. In the 1- and 4-year old stands in the Luoyangjiang Estuary, $K$. candel forests had a higher density of twigs and foliage than those in A. corniculatum forests. Snelgrove and Butman (1994) and Alfaro (2006) demonstrated that areas within various vegetation types can support significantly different macro-benthic assemblages. These different mangrove vegetation types alter micro-environmental and benthic assemblage parameters (i.e. diversity) in various ways and are highly correlated with these environmental parameters (Islam et al. 2007). While crabs live in burrows, they also leave their burrows to forage. The microterrain environment of mangroves provides a safe and protected habitat for crabs. There was a significant difference between the burrow densities under mature $K$. candel and A. corniculatum trees $(p<0.05)$. Macintosh et al. (2002) compared the characteristics of the composition and distribution of macro-benthic animals in restored and natural mature Ronan mangroves in Thailand. He found that snail densities of Neritidae and Ellobiidae in natural forest were greater than in restored mangrove forest, while populations of freshwater crabs in the family Potamidae were higher in young artificially 


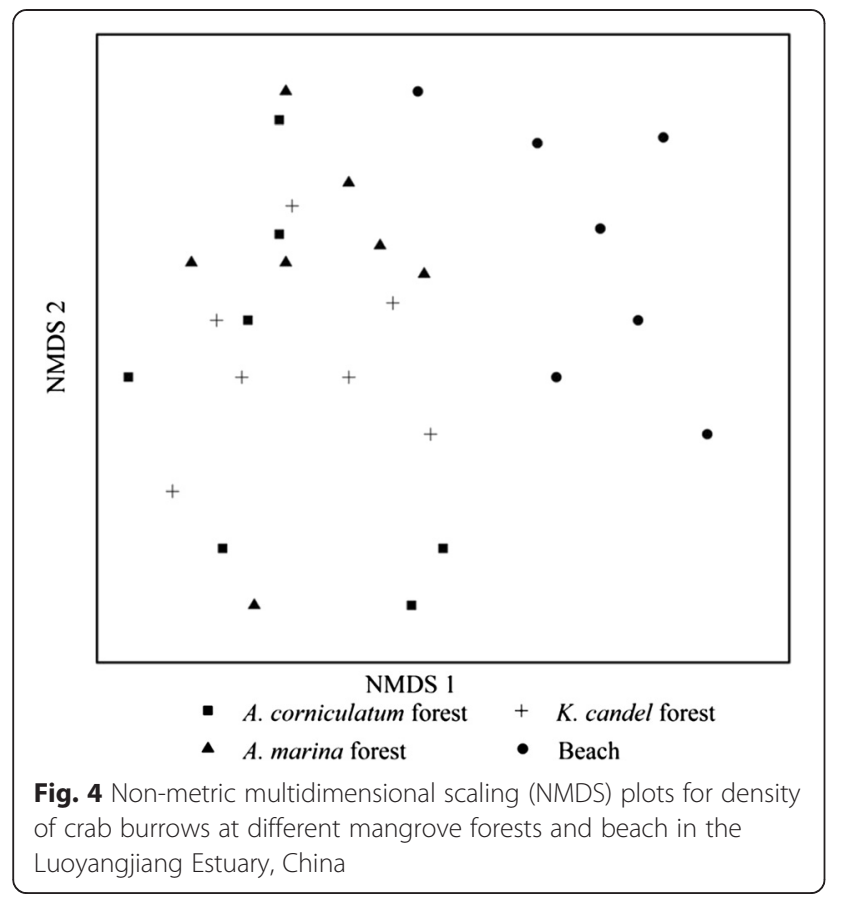

restored mangroves. The various types of mangrove vegetation create differences in environmental factors that affect the density, biomass and abundance of benthic organisms. This explains the differences in our findings that show crab burrow density varies in mangroves with the three mangrove species $K$. candel, A. corniculatum and $A$. marina. Mangrove vegetation contributes to habitat complexity and diversity of associated fauna (Hutchings and Saenger 1987; Lee 1998; Lee 2008). In New Zealand, Morrisey et al. (2003) found larger numbers of macro-benthic species in areas of younger artificially restored $A$. marina saplings than in areas of older artificially restored $A$. marina sites.

As well, we analyzed crab burrow density under four different types of mangrove forests and beach, based on NMDS. Our results showed marginal similarities of crab burrow density on the beach and in the three different natural mature mangrove forests. But our result also show high similarities of crab burrow densities among the natural mature mangrove species (Fig. 4). The opposite results suggest that the presence of natural mature mangroves has a significant effect on the density of crab burrows.

\section{Effects of mangrove species and canopy cover}

Two-factor ANOVA showed that mangrove species and canopy cover had significant impacts on crab burrow density (Table 2). This density decreased with an increase of A. corniculatum forest canopy cover (Fig. 5), while the $K$. candel forest did not show a clear connection between burrow density and different percentages of canopy cover (Fig. 6). Crabs belonging to the family Ocypodidae are the most common species in the Luoyangjiang Estuary, since these fiddler crabs are efficient consumers of benthic microalgae (Kristensen and Alongi 2006). Thus Ocypodidae crabs strongly respond to an abundance of microalgae in surface sediment. Further, algal biomass can also be affected by varying light intensity under different levels of canopy cover (Alongi 1988).

The canopy cover of mangrove species had some effect on the density of crabs, which might be explained by differences in available shade. Nobbs (2003) found that Uca spp. crabs were affected more by the availability of shade than by vegetation structure, because shade decreases the effect of high temperatures and high rates of

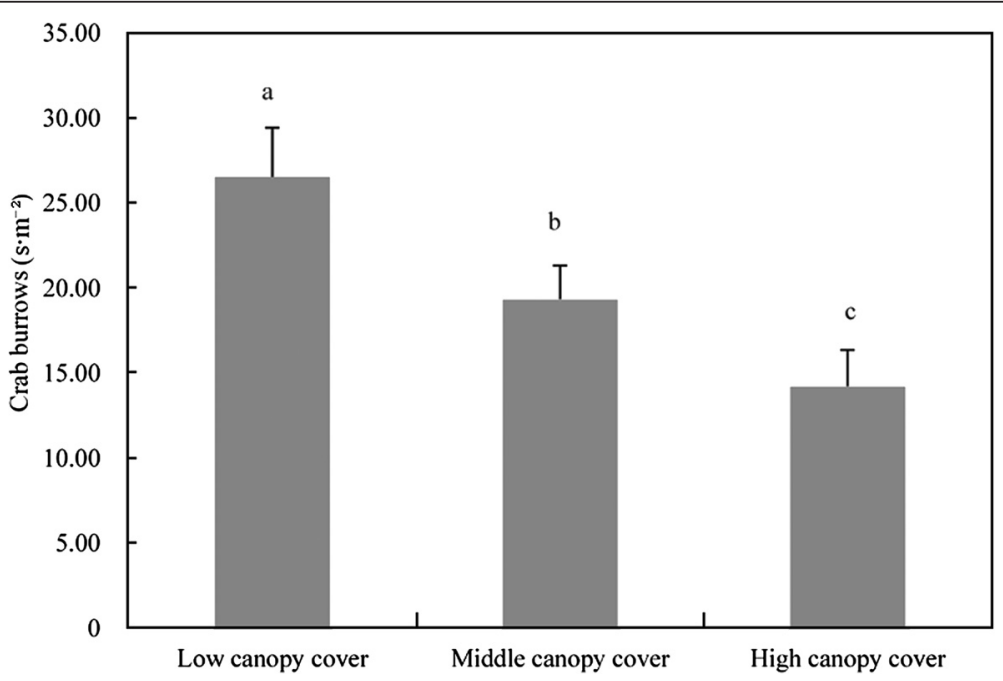

Fig. 5 Differences in density of crab burrows under A. corniculatum and various canopy covers 


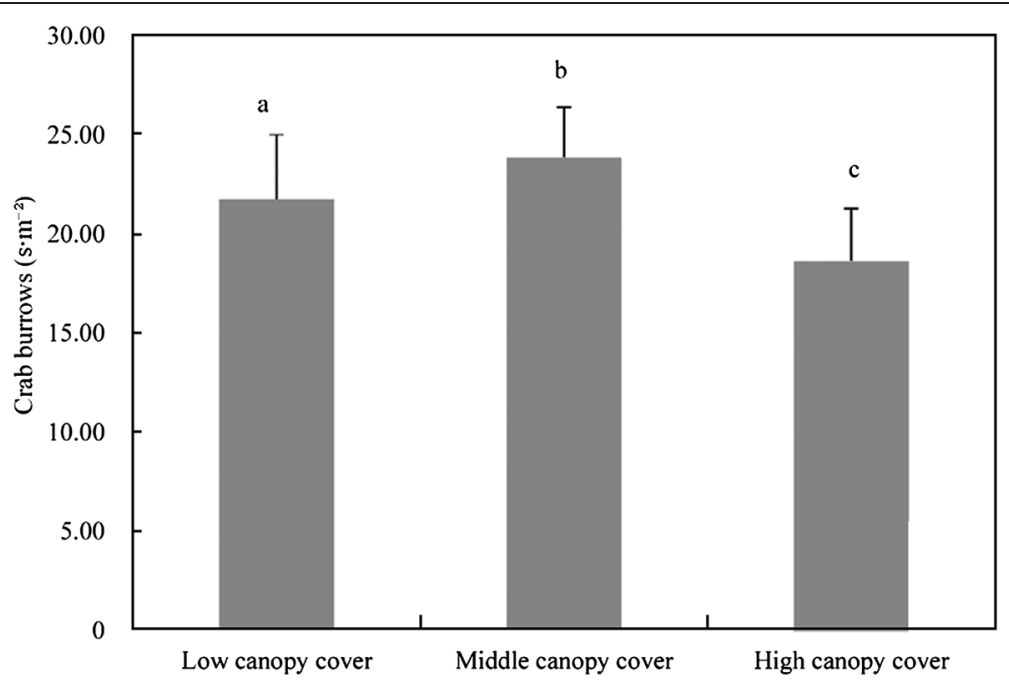

Fig. 6 Differences in density of crab burrows under $K$. candel and various canopy covers

evaporation. Light intensity within the mangrove sites changed with canopy cover, which could affect the distribution of crabs. We found that the distributions of some crab species are affected by the availability of shade in mangroves; shade provided by mangrove trees may reduce high temperatures and high rates of water evaporation in the intertidal zone, which can affect benthic organisms. Inga et al. (2009) found several exogenous factors, such as a particular light, leaf litter availability and flooding of burrows, to be important in controlling the activity pattern of crabs in a high intertidal mangrove forest.

Figure 7 shows negative relationships between crab burrow density and mangrove canopy cover. The number of crab burrows under $A$. corniculatum and $K$. candel decreases as the canopy cover increases. The number of crab burrows is more closely related to canopy cover for $A$. corniculatum than for $K$. candel. Our investigation confirms that the environment of mangrove forests, such as humidity and the transmission of light, affects the development of crabs (Nobbs 2003; Inga et al. 2009).

\section{Conclusions}

There were clear differences in the density of crab burrows on the beach and in mature $K$. candel, A. corniculatum and A. marina communities. The effect of mangrove plant species and stand age on crab burrow density is different. Mangrove species and canopy cover have

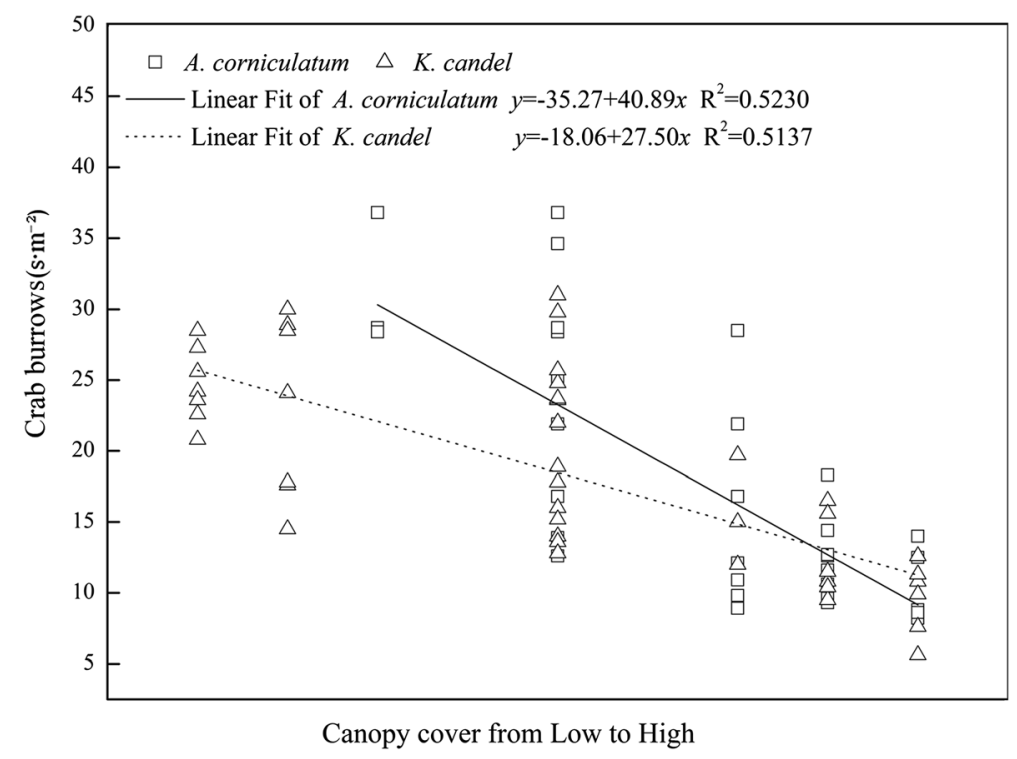

Fig. 7 Regression of crab burrows on canopy cover for A. corniculatum and K. candel 
significant impacts on crab burrow density. In order to restore mangroves scientifically and rationally, it is important to take the combined effects of mangrove stand age, canopy cover and other factors into account.

\section{Competing interests}

The authors declare that they have no competing interests.

\section{Authors' contributions}

All authors conceived the study. All authors helped to draft the manuscript. All authors read and approved the final manuscript.

\section{Acknowledgments}

This study was funded by the Special Forestry Project of Public Interests (201404305). We thank Xin Tian and Yanmei Wu for valuable comments on the draft of this paper as well as Yujuan Chen, Shiqi Tang and Edanz Editing China for linguistic assistance.

\section{Received: 19 December 2014 Accepted: 2 July 2015}

Published online: 15 July 2015

\section{References}

Alberti J, Escapa M, Iribarne O, Silliman B, Bertness M (2008) Crab herbivory regulates plant facilitative and competitive processes in Argentinean marshes. Ecology 89:155-164

Alfaro AC (2006) Benthic macro-invertebrate community composition within amangrove/seagrass estuary in northern New Zealand. Estuar Coast Shelf Sci 66:97-110

Alongi DM (1988) Bacterial productivity and microbial biomass in tropical mangrove sediment. Microb Ecol 15:59-79

Błażewicz-Paszkowycz M, Pabis K, Jóźwiak P (2014) Tanaidacean fauna of the Kuril-Kamchatka Trench and adjacent abyssal plain - Abundance, diversity and rare species. Deep Sea Research Part II: Topical Studies in Oceanography. doi:10.1016/j.dsr2.2014.08.021

Brockmeyer RE, Rey JR, Virnstein RW, Gilmore RG, Earnest L (1997) Rehabilitation of impounded estuarine wetlands by hydrologic reconnection to the Indian River Lagoon, Florida (USA). Wetl Ecol Manag 4:93-109

Bui THH, Lee SY (2015) Endogenous cellulase production in the leaf litter foraging mangrove crab Parasesarma erythodactyla. Comparative Biochemistry and Physiology Part B: Biochemistry and Molecular Biology 179:27-36

Carlos L, Yolanda M, Fernando LMM (2005) Population biology and breeding period of the Sand-Bubbler Crab Dotilla Fenestrata (Brachyura: Ocypodidae) from Southern Mozambique. Aquat Ecol 39(3):305-313

Chen GC, Ye Y (2011) Restoration of Aegiceras corniculatum mangroves in Jiulongjiang Estuary changed macro-benthic faunal community. Ecol Eng 37:224-228

Chen GC, Ye Y, Lu CY (2007) Changes of macro-benthic faunal community with stand age of rehabilitated Kandelia candel mangrove in Jiulongjiang Estuary, China. Ecol Eng 31:215-224

Cui LJ, Stephane A (2006) The wetland restoration handbook: guiding, principles and case studies. China Architecture and Building Press, pp 88-102

Cyril P, Uta B, Ilka CF (2009) Spatial structure of a leaf-removing crab population in a mangrove of North-Brazil. Wetl Ecol Manag 17:93-106

Erik K (2008) Mangrove crabs as ecosystem engineers, with emphasis on sediment processes. J Sea Res 5:30-43

Fan HQ (2000) Mangrove as a coastal environmental guarder. Guangxi Science and Technology Press, Nanning, p 148

Feller IC, Chamberlain A (2007) Herbivore responses to nutrient enrichment and landscape heterogeneity in a mangrove ecosystem. Oecologia 153(3):607-616

Food and Agricultural Organization (FAO) (2003) New global mangrove estimate. http://www.fao.org/forestry/foris/webview/forestry2/ index.jsp\%3Fgeold $=0 \% 26$ langid.

Gawlik DE (2006) The role of wildlife science in wetland ecosystem restoration: lessons from the Everglades. Ecological Engineering 26:70-83.

Gianluca P (2009) Species-area relationship and potential role as a biomonitor of mangrove communities of Malayan mudskippers. Wetl Ecol Manag 17:157-164
Giri C, Pengra B, Zhu ZL, Singh A, Tieszen LL (2007) Monitoring mangrove forest dynamics of the Sundarbans in Bangladesh and India using multi-temporal satellite data from 1973 to 2000. Estuar Coast Shelf Sci 73:91-100

Giulia C, Laurent D, Philippe M (2008) An object-based method for mapping and change analysis in mangrove ecosystems. ISPRS J Photogramm Remote Sens 63:578-589

Granek EF, Frasier K (2007) The impacts of red mangrove (Rhizophora mangle) deforestation on zooplankton communities in bocas deltoro, Panama. Bull Mar Sci 80(3):905-914

Huang ZG (2004) Biodiversity on marine estuarine wetland. Ocean Press, Beijing (in Chinese)

Hutchings P, Saenger P (1987) Ecology of Mangroves. University of Queensland Press, St. Lucia, Australia, p 388

Inga N, Karen D, Matthias W (2009) Activity patterns, feeding and burrowing behaviour of the crab Ucides cordatus (Ucididae) in a high intertidal mangrove forest in North Brazil. J Exp Mar Biol Ecol 374:104-112

Islam SSM, Prosper LM, Makoto T (2007) Bioturbation activity by the grapsid crab Helice formosensis and its effects on mangrove sedimentary organic matter. Estuar Coast Shelf Sci 73:316-324

Kristensen E, Alongi DM (2006) Control by fiddler crabs (Uca vocans) and plant roots (Avicennia marina) on carbon, iron, and sulfur biogeochemistry in mangrove sediment. Limnol Oceanogr 51:1551-1557

Lee SY (1998) Ecological role of grapsid crabs in mangrove ecosystems: a review. Mar Freshwater Res 49:335-343

Lee SY (2008) Mangrove macrobenthos: assemblages, services, and linkages J Sea Res 59:16-29

Lewis RR (2000) Ecologically based goal setting in mangrove forest and tidal marsh restoration in Florida. Ecol Eng 15:191-198

Li R, Ye Y, Chen GC, Weng J (2007) Effect of Aegiceras corniculata mangrove rehabilitation on macro-benthic animals in Jiulongjiang river estuary. J Xiamen Univ (Natural Science) 46:109-114 (in Chinese)

Li W, Cui LJ, Zhang MY, Wang YF (2009) Landscape pattern change of mangrove wetlands and its surrounding region in the estuary of Luoyang river, Fujian Province. Wetl Sci 7:53-59 (in Chinese)

Lin P (1999) Mangrove research Proceedings (The third edition). Xiamen University Press 11-18 (in Chinese)

Liu RC (2010) Huian luo yangjiang mangrove. China Forestry Press, China. Beijing, pp 99-135 (in Chinese)

Macintosh DJ, Ashton EC, Havanon S (2002) Mangrove rehabilitation and intertidal biodiversity: a study in the Ranong mangrove ecosystem, Thailand. Estuar Coast Shelf Sci 55:331-345

Marcelo CL, Cohen RJL (2003) Temporal changes of mangrove vegetation boundaries in Amazonia: Application of GIS and remote sensing techniques. Wetl Ecol Manag 11:223-231

Micheli F, Gherardi F, Vannini M (1991) Feeding and burrow ecology of two East African mangrove crabs. Mar Biol 111:247-254

Morrisey DJ, Skilleter GA, Ellisa JI, Burnsc BR, Kempa CE, Burta K (2003) Differenees in benthic fauna and sediment among mangrove (Avieennia marina var. australasica) stands of different ages in NewZealand. Estuar Coast Shelf Sci 56:581-592

Nobbs M (2003) Effects of vegetation differ among three species of fiddler crabs (Uca spp.). J Exp Mar Biol Ecol 284:41-50

Paling El, Kobryn HT, Humphreys G (2008) Assessing the extent of mangrove change caused by Cyclone Vance in the eastern Exmouth Gulf, northwestern Australia. Estuar Coast Shelf Sci 77:603-613

Phan MT, Jacques P (2007) Status and changes of mangrove in Mekong Delta: Case study in TraVinh, Vietnam. Estuar Coast Shelf Sci 71:98-109

Poovachiranon S, Tantichodok P (1991) The role of sesarmid crabs in the mineralisation of leaf litter of Rhizophora apiculata in a mangrove, southern Thailand. Phuket Mar Biol Cent Res Bull 56:63-74

Primavera JH, Esteban JMA (2008) A review of mangrove rehabilitation in the Philippines: successes, failures and future prospects. Wetl Ecol Manag 16:345-358

Robertson Al, Daniel PA (1989) The influence of crabs on litter-processing in high intertidal mangrove forests in tropical Australia. Oecologia 78:191-198

Roslan H, Babak K, Noraini MT, Rozainah Z (2010) An integrated approach to coastal rehabilitation: Mangrove restoration in Sungai Haji Dorani, Malaysia. Estuar Coast Shelf Sci 86:118-124

Rubih HC, Nico K, Arturo RL, Max T, Farid DG (2007) Remote sensing and ethnobotanical assessment of the mangrove forest changes in the Navachiste-San Ignacio-Macapule lagoon complex, Sinaloa, Mexico. Ecol Soc 10:16-26 
Ruwa RK (1997) Zonation of crabs that burrow or bury in mangrove vegetation soils on the east coast of Kenya. In: Kjerfve B, Lacerda LD, Diop S (eds) Mangrove Ecosystem Studies in Latin America and Africa. UNESCO, Paris, pp 316-324

Saenger P (1996) Mangrove restoration in Australia: a case study of Brisbane international airpoat. In: Field CD (ed) Restoration of Mangrove Ecosystems. International Society for Mangrove Ecosystems, Okinawa, Japan, pp 36-51

Salgado KCP, McGuinness KA (2006) A comparison of methods for estimating relative abundance of grapsid crabs. Wetl Ecol Manag 14:1-9

Samidurai K, Saravanakumar A, Kathiresan K (2012) Spatial and temporal distribution of macrobenthos in different mangrove ecosystems of Tamil Nadu Coast, India. Environ Monit Assess 184(7):4079-4096

Sanyal P (1998) Rehabilitation of degraded mangrove forests of the Sunderbans of India. In: Program of the International Workshop on Rehabilitation of Degraded Coastal Systems, Phuket Marine Biological Center, Phuket, Thailand 19-24, 25

Schories D, Barletta-Bergan A, Barletta M, Krumme U, MehligU VRV (2003) The keystone role of leaf-removing crabs in mangrove forests of North Brazil. Wetl Ecol Manag 11:243-255

Serena L, Thomas AS, Simon W (2009) Monitoring human impacts on sandy shore ecosystems: a test of ghost crabs (Ocypode spp.) as biological indicators on an urban beach. Environ Monit Assess 152:413-424

Skov MW, Vannini M, Shunula JP, Hartnoll RG (2002) Quantifying the density of mangrove crabs: ocypodidae and grapsidae. Mar Biol 141:725-732

Slim FJ, Hemminga MA, Ochieng C, Jannink NT, Cocheret ME, Vander VG (1997) Leaf litter removeal bythe snail Terebralia palustris (Linnaeus) and sesarmid crab inan East African mangrove forest (Gazi Bay, Kenya). J Exp Mar Biol Ecol 215:35-48

Smith TJIII, Boto KG, Frusher SD, Giddins RL (1991) Keystone species and mangrove forest dynamics: The influence of burrowing by crabs on soil nutrient and forest productivity. Estuar Coast Shelf Sci 33:419-432

Snelgrove PVR and Butman CA (1994) Animal-sediment relationships revisited: cause versus effect. Oceanogr Mar Biol 32:111-177.

Sokal RR, Rohlf FJ (1995) Biometry: The principles and practice of statistics in biological research. Freeman, New York

Stacy LO, Marvin EB (2002) Satellite remote sensing of wetlands. Wetl Ecol Manag 10:381-402

Steinke TD, Rajh A, Holland AJ (1993) The feeding behaviour of the red mangrove crab Sesarma meinertii De Man, 1887 (Crustacea: Decapoda: Grapsidae) and its effect on the degradation of mangrove leaf litter. Afr J Mar Sci 13:151-160

Teal JM (1958) Distribution of fiddler crab in Georgia salt mashese. Ecology 39:185-193

Wang M, Gao XQ, Wang WQ (2014) Differences in burrow morphology of crabs between Spartina alterniflora marsh and mangrove habitats. Ecol Eng 69:213-219

Warren JH (1990) The use of open burrows to estimate abundances of intertidal estuarine crabs. Aust J Ecol 15:277-280

Zheng DZ, Li M, Zheng SF, Liao BW, Chen YJ (2003) Headway of study on mangrove recovery and development in China. Guangdong For Sci Technol 19:10-14 (in Chinese)

\section{Submit your manuscript to a SpringerOpen ${ }^{\circ}$ journal and benefit from:}

- Convenient online submission

- Rigorous peer review

- Immediate publication on acceptance

- Open access: articles freely available online

- High visibility within the field

- Retaining the copyright to your article

Submit your next manuscript at $>$ springeropen.com 